\title{
El Sentimiento de la Naturaleza en la Moderna Poesía del Perú
}

\section{Introducción}

$\mathbf{U}^{\mathrm{N}}$ $\mathrm{N}$ estudio sobre el sentimiento de la naturaleza en la poesía se sustenta en el lugar común, y por tal irrebatible, de que toda expresión literaria está más o menos vinculada al paisaje que vive o vivió su creador. La mayor o menor acentuación de tal vínculo depende de la época en que la obra se produce. Hay tiempos en que el poeta se retrae y trata de prescindir de la naturaleza que le rodea; existen épocas en que el artista se nutre y se afirma en el paisaje circundante. En este último caso, la naturaleza es fin, mientras en el primero era únicamente medio, pretexto o bambalina. En qué medida el artista se acerca a su mundo natural circundante o se aleja de él, es problema que corresponde investigar a la crítica, y que nosotros sepamos, tal estudio no se ha hecho todavia dentro de la literatura del Perú.

Este ensayo, pues, intenta -y éste es tal vez su único méritoabrir un campo de investigación todavía intocado por los investigadores del Perú, y como todo primer intento, quiere ser muy parco en sus conclusiones y bastante reducido en su extensión, que abarca únicamente los últimos cuarenta años del fenómeno poético peruano. Tal vez haya oportunidad futura para ampliar sus límites a la prosa y a la poesía de ésta y otras épocas literarias.

Quisiéramos averiguar la verdad o falsedad de algunas afirmaciones críticas que todavía no se han esclarecido. Se dijo profusamente en cierta época y por ciertos críticos que los "modernistas". 
se habían acercado intensamente al paisaje americano. En lo que se refiere al Perú, sería interesante establecer hasta qué punto es verdadero dicho aserto.

Si en cualquier región de la tierra este problema de la aproximación del artista a su ambiente es de vital importancia, mucho más 1o es en nuestra América, en donde lo telúrico cobra tanto vigor. Ya lo ha propuesto con su fina sensibilidad Alfonso Reyes, en un reciente ensayo: "En la investigación y desctibrimiento de nuestro ser americano - dice el autor de Visión de Anáhuac- el paisaje, en el más vasto sentido del término, debiera estar siempre presente: el paisaje como tierra y cielo, como aire y luz."

Estas palabras preclaras animan nuestra empresa de indagar el concepto de naturaleza que prevalecía en los poetas, desde la época que los historiadores de la literatura titulan "modernismo" hasta las últimas manifestaciones de la poesía nueva.

Los poetas que hicieron "modernismo" en el Perú no constituyen, estrictamente hablando, una generación literaria. Dicho grupo, o por mejor decir, tal agrupación, tiene como característica esencial su heterogeneidad y excede, con mucho, las condiciones fijadas por Petersen para constituir "generación", en la estricta acepción que confiere a este término la moderna ciencia de la literatura.

En verdad, sólo hubo un "modernista" en el Perú: José Santos Chocano. Los demás poetas contemporáneos suyos, que llenan los años finales del siglo anterior y los iniciales del siglo $\mathrm{xx}$, son poetas en quienes todavía influye preponderantemente el romanticismo $\mathrm{y}$, en consecuencia, no corresponde estudiarlos en un ensayo que versa sobre el concepto del paisaje a partir de los modernistas.

Es ésta la razón por la cual la poesía de Chocano tiene que merecer un detenido examen, porque es la propiamente "modernista" y la que define con todo rigor las inquietudes más características de su época.

Pero entre Chocano y la nueva poesía, existe en la encrucijada un poeta de honda significación y rara trascendencia en la literatura del Perú: José María Eguren. Acaso al par que ofrece uno de los más logrados aspectos del paisaje peruano, los sembradíos de la costa dentro de sus limitados valles, constituye el tránsito entre el concepto "modernista" de la naturaleza y la teoría directa de los poetas últimos de inclinación expresionista. 


\section{El "Modernismo"}

Examinando la actitud frente a la naturaleza de poetas como Luis Fernán Cisneros, Leonidas Yerovi, Alberto Ureta, José Gálvez, Abraham Valdelomar y Enrique Bustamante en sus primeros poemas, tenemos que concluir que el paisaje no es sino el reflejo del alma atormentada, que no existe como cosa objetiva sino meramente como reflejo de sus particulares estados de ánimo. Aquellos poetas no ven el paisaje, sino que lo construyen a su imagen y semejanza. Evitando el tomarlo tal cual es, recurren a verdaderos telones, como aquellas noches con luna y árboles y fuentes de encantamiento a que son $\tan$ afectos. O bien, se proyectan a visiones de llano y convencional orientalismo. Sus creaciones son, por lo general, inespaciales y no localizables. Igualmente romántico, por su concepción de la naturaleza, es Manuel González Prada, autor de las Baladas peruanas, en las cuales volcó una seria preocupación historicista y sociológica, sin pretender ubicar a su indio dentro del marco natural. Eran sus baladas un eco de la leyenda romántica a lo Zorrilla con personajes peruanos, en el molde germánico, pero sin vínculo verdadero que lo ligara con la naturaleza del país.

Dentro de esta época, hay dos momentos importantes en cuanto a la concepción del paisaje. El que encarnan los poetas últimamente nombrados y el que resume José Santos Chocano.

A los primeros podemos analizarlos a través de dos de sus más caracterizados teorizadores: Abraham Valdelomar y Enrique Bustamante y Ballivián.

"El arte - decía Valdelomar - es la naturạleza vista a través de un espíritu." Con ello no hacía sino glosar las ideas de Oscar Wilde, paradójicas elucubraciones de un artista exquisito y decadente. Pero añadía Valdelomar: "Mejor aún, el arte es un instante de naturaleza a través de un estado de alma; aún más: un instante de infinito plasmado en una sensación. Tienen las cosas exaltaciones y depresiones. Tiene la naturaleza instantes de revelación en los cuales se diría que está elocuente, que habla, que quisiera comunicarse con los hombres." $\mathrm{Y}$ así era en efecto: aquellos poetas tomaban la naturaleza como un medio para excitar su propia inspiración, pero sin inspirarse en ella, como un estímulo para su íntima elucubración, pero sin adentrarse en sus secretos y bellezas; como un recurso de utili- 
zación individual y subjetiva, pero sin concederle personeria artística y universal. "Un crepúsculo, una aurora, una escultura o un monumento -afirmaba en un ensayo Enrique Bustamante y Balliviánllevan en sí un poder de evocar que guarda relación con las anteriores sensaciones del espectador, un poder cuya capacidad depende del conocimiento de las impresiones producidas en diversas personalidades artísticas por un fenómeno o un aspecto de la naturaleza. Quien haya estudiado el paisaje a través de muchas escuelas y temperamentos, encuentra en cada visión un sedimento de alma dejado por los artistas que nos descubrieron los desconocidos aspectos, a la vez que surgen evocados por la analogía de la sensación visual, los momentos de nuestra vida en que contemplamos análogos objetos bajo la intensidad de un sentimiento profundo e inolvidable o una emoción de belleza que nos descubrió la eterna armonía universal."

La obsesión de infinito que caracteriza a estos poetas los hace considerar el paisaje natural como un escalón inevitable, pero asimismo intrascendente. El poeta no puede quedarse en el marco de la naturaleza, demasiado parca y limitada para sus ansias de trascendencia e infinitud. El bello escenario natural de una de las ciudades del Perú mejor dotadas por el paisaje, Jauja, sirve a Valdelomar como el marco sugestivo para una fantasía trágica que es "La ciudad de los tísicos". La maravillosa perspectiva andina o la atracción artística de la laguna de Paca, en los aledaños de dicha ciudad, no conmueven al poeta sino en la medida en que pueden ellos estimular su espíritu sediento de sensualismo y refinamiento. $\mathrm{Y}$ así dice Bustamante refiriéndose a dicha obra de Valdelomar: "La ciudad encantada en que bajo la lluvia y la tempestad andina viven los tísicos, entre el amor y la muerte, tiene una atmósfera de tragedia y lubricidad, un ambiente de Lorraine en que los personajes de mejillas sonrosadas y de bocas rojas de sangre se extinguen en una fiebre de deseo como los Noronsoff en su locura ante el mar puro y el cielo claro de la Costa Azul."

Aquel grupo de poetas seguía el mandato de Mallarmé: "evocar poco a poco un objeto para descubrir un estado de alma e, inversamente, escoger un objeto y extraer un estado de alma por una serie de desciframientos." De tal grupo en aquella época, no pudo pues. quedar siquiera un retazo del paisaje peruano. Pero los años pasan, las exaltaciones juveniles se amenguan, las hipérboles decaen y la madurez llega a ellos. $\mathrm{Y}$ entonces aquellas mismas almas atormen- 
tadas de refinamiento e infinitud, cuya vaguedad espiritual, como decía un poeta, "tiene muchas analogías con la visión crepuscular en que las cosas pierden su perfil y su relieve", van a trocar su actitud ante el paisaje.

Valdelomar, el propio autor de "La ciudad de los tísicos", años después nos ofrecerá el cuadro vibrante de su pueblo natal, de ese Pisco aldeano que pinta con realismo sin igual en El caballero Carmelo (Lima, 1918). No hemos tenido todavía descriptor más sensibilizado a la emoción del paisaje de nuestros pueblos humildes que el que se demuestra Valdelomar en aquel trozo de autobiografía.

Bustamante y Ballivián, viajero por nuestros Andes Centrales, tiempos después nos da la visión de Junín, en un libro de poemas dictado por las impresiones de aquella "alta tierra generosa cuyo color se prendió a mis pupilas", según confiesa el mismo poeta.

José Gálvez viró el rumbo de su poesía hacia esos cuadros de vida costeña y criolla que son "La Marinera" y "La jazminera" en que, sin premeditación, el poeta se ha alejado de

Yo, la luna y mis soñadas divagaciones

de sus comienzos, para dibujar con rápidos trazos a la

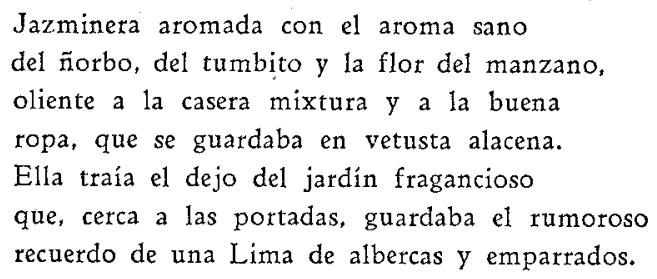

Como ligadura entre los poetas anotados y las nuevas generaciones, a manera de tránsito, se anuncian los poemas de Los heraldos negros (Lima, 1918), de César Vallejo, entre los cuales está "Aldeana", que subyuga por su agudo tono eglógico:

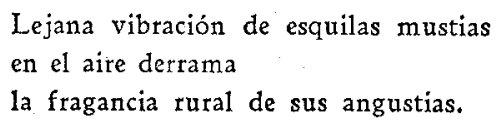


En el patio silente

sangra su despedida el sol poniente.

El ámbar otoñal del panorama

toma un frío matiz de gris doliente!

Al portón de la casa

que el tiempo con sus garras torna ojosa,

asoma silenciosa

y al establo cercano luego pasa,

la silueta calmosa

de un buey color de oro,

que añora con sus bíblicas pupilas

oyendo la oración de las esquilas

su edad viril de toro.

Al muro de la huerta, aleteando la pena de su canto,

salta un gallo gentil $y$, en triste alerta,

cual dos gotas de llanto,

tiemblan sus ojos en la tarde muerta!

Lánguido se desgarra

en la vetusta aldea

el dulce yaraví de una guitarra,

en cuya eternidad de hondo quebranto

la triste voz de un indio dondonea,

como un viejo esquilón de camposanto.

De codos yo en el muro,

cuando triunfa en el alma el triste oscuro

$y$ el viento reza en los ramajes yertos

llantos de quenas, tímidos, inciertos,

suspiro una congoja,

al ver que en la penumbra gualda y roja

llora un trágico azul de idilios muertos!

E1 sabor campesino de las estrofas precedentes se reitera en otros dejos poéticos que tampoco han dejado de ser decadentes, pero que aparecen ya compenetrados del sentido de la naturaleza de las aldeas y campos del Perú. Juan Parra del Riego, antes de seguir la huella de aventura y el afán de ganar otros horizontes que caracterizó a su maestro en el lustre y el ímpetu, que fué Chocano, ensaya tímidamene este bosquejo idílico:

¡Oh Surco, melancólico y desierto!

¡Oh Surco, viejo pueblo campesino! 
Eres así como ataúd abierto y olvidado a la vera del camino.

Al ver tu soledad siento la mía, y entre esa doble sensación de espanto, de abandono y mortal melancolía, no sé cuál de las dos es la que canto.

¡Oh tu iglesia caduca y empolvada, ante la triste plaza despejada por donde un són de esquilas va pasando!

Tiene un mistico espanto tan silente, que recuerda una abuela que rezando se quedara dormida de repente.

Aquella gris perspectiva del pueblo limeño, contrasta con la luz del pueblo arequipeño que en estos versos imprimiera Percy Gibson:

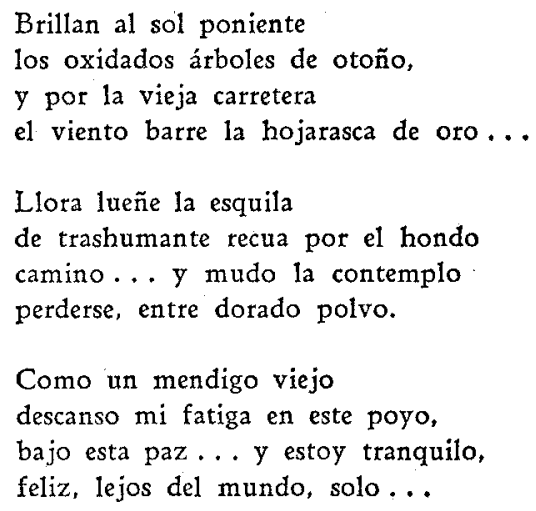

El segundo momento en la concepción del paisaje en esta época, la constituye José Santos Chocano. Pero para comprender su obra, y sobre todo su sentido de la naturaleza, es absolutamente preciso esbozar una breve apuntación biográfica. Pues Chocano no sólo pretendió haber captado las esencias del paisaje del Perú, sino que su ambición e impulso vital lo llevó a creerse, antes que nada, el poeta de América meridional. Ya lo dice en uno de sus poemas de Alma América:

Walt Whitman tiene el norte; pero yo tengo el sur. 
$Y$ en otro que titula "El dorado", agregará: "América es mi sola fuente de poesía." Estamos, pues, ante un creador que no sólo quiere ser el intérprete de un paisaje regional, sino que, ante todo, persigue recoger en sus versos el sentido y la faz de todo un continente. La vastedad de su propósito y la amplitud de su campo de acción requiere, pues, un estudio detenido.

\section{José Santos Chocano}

Era casi un niño cuando Chocano, en 1890 , hizo sus primeras armas literarias en un periódico titulado Fin de Siglo. Aún lo ligaban mayores vínculos con la poesía del argentino Olegario Andrade o de los mexicanos post-románticos como Gutiérrez Nájera, Manuel M. Flores, Manuel Acuña, Juan de Dios Peza y Salvador Díaz Mirón, que con las recientes apariciones de la prosa o de la poesía de Rubén Darío. Entonces despuntaba su romanticismo, a veces blando y nupcial como en Azahares, a veces iracundo y exaltado como en Iras santas, a veces eglógico, aunque sin regionalismo, como En la aldea.

Ganaba prematuramente, antes de cumplir los dieciocho años, la consagración literaria nacional y americana. Su americanismo nació de su frecuente correspondencia con los poetas del continente y de la boga que tuvieron en Lima Los poetas mexicanos (Buenos Aires, Imp. E. Coni, 1896), que es título de un libro escrito por el poeta peruano Carlos Germán Amézaga. Sin embargo, su actitud ante el paisaje pudo entonces haber sido estimulada con estas palabras de Amézaga, incluidas en el tomo mencionado: "Muy engañados están los que se figuran encontrar poesía americana en ciertas composiciones descriptivas de nuestras ciudades y montes, de nuestras florestas y ríos. En nada se manifiesta precisamente la imitación servil, como en estos trabajos, donde campean imágenes y conceptos que ya eran de respetable antigüedad con el Arcipreste de Hita y con Garcilaso. Frases vetustas hay que continúan haciendo las delicias de nuestros bardos en sus mejores versos, como si no se atrevieran a combinar otras en presencia de una naturaleza que por variada $y$ por rica no tiene igual, y que parece invitar a que se la cante con ritmos nuevos, con voces que al sonar no recuerden las canturías del viejo mundo." 
Chocano tomó, desde 1896, su posición frente al paisaje americano. Son suyas estas palabras extraídas de un artículo aparecido en La Neblina: "Pero no es simplemente la aspiración, el sentimiento, la idea lo que determina el poema, ni basta la suficiencia artística; es preciso buscar el medio ambiente propicio para el desarrollo; para cantar las selvas amazónicas, es preciso internarse en ellas, vivir con su vida robusta, sentir el roce áspero de su naturaleza." Pero agregaba que esa necesidad era insalvable: "los medios de movilización no se presentan sino con la fortuna. Hoy por hoy, estamos condenados a vegetar entre los cuatro estrechos muros de la ciudad: la selva no se ha hecho para nosotros..."

Hasta entonces igualmente no había rastro de paisaje pertano o americano en su obra. Es paradójico que un libro suyo de esta época se titulara Selva virgen (1896), pues el contenido no responde a tal denominación. Si no era consecuente el título sí lo era el contenido, pues Chocano no pretendió todavía localizar su paisaje y estaba de acuerdo con sus teorizaciones. Por ese tiempo también decía: "Cantamos lo que podemos ver con nuestros propios ojos, cantamos lo que podemos cantar con nuestras propias manos, la inspiración necesita de impresiones previas." Lentamente se acercaba al ideal de Amézaga: ver las cosas de América con nutevos ojos y registrar esas impresiones con nueva técnica. En cuanto Chocano pudo viajar, su obra se nutre de impresiones del paisaje peruano. Pero desafortunadamente conoció poco del Perú; su destino trató siempre de sustraerlo del país natal y los años decisivos y los de la madurez transcurren dentro de América, pero lejos de la tierra peruana. Al par que renovaba ritmos, cantaría con voz nueva, sin parangón con otros sones poéticos extraños, y a base de motivos de la naturaleza y de la historia americana.

Hemos dicho que conoció poco del Perú. Veamos las circunstancias que rodean ese conocimiento. Cuando en 1899 Javier Prado emprenđió la reorganización de "E1 Ateneo de Lima", y fué el gestor de la aparición de su revista El Ateneo, después de diez años de receso, publicó en esa revista dos grandes poemas de Chocano, plenos de madura concepción y de neta inspiración peruana: ellos son "El derrumbe", que más tarde en sus reediciones titularía "El derrumbamiento", y "La epopeya del Morro", con el que ganó sonoramente un concurso. 
En esa época, que es en el Perú de transformaciones políticas, en la que la inquietud de la explotación industrial del territorio ganaba voluntades e idealismos, se planteó como problema nacional el enlace entre la selva y la costa, a raíz de un intento abortado de separatismo en el oriente. Los historiadores han señalado la trascendencia de los intentos de penetración en la floresta que entonces se iniciaron por la sección central del pais, desde Lima hacia los ríos Pichis y Ucayali. El impulso inicial se dió haciéndose practicable el tráfico al valle de Chanchamayo, región en donde había prosperado, en el siglo xviII, la célebre rebelión de Juan Santos Atahualpa. A este empeño de integración nacional había estado vinculada la actividad de un político emprendedor, don Joaquín Capelo, hombre al par de acción y de humanidades, amigo de los hombres de letras y por lo tanto de Chocano. Habría éste último recorrido el tramo caminero recién inaugurado hasta los cafetales de Chanchamayo, según podría deducirse de algunas descripciones de "El derrumbe", tal vez el único poema en que Chocano ha tratado con feliz aproximación y relativa fidelidad la naturaleza peruana. Así lo revela este fragmento

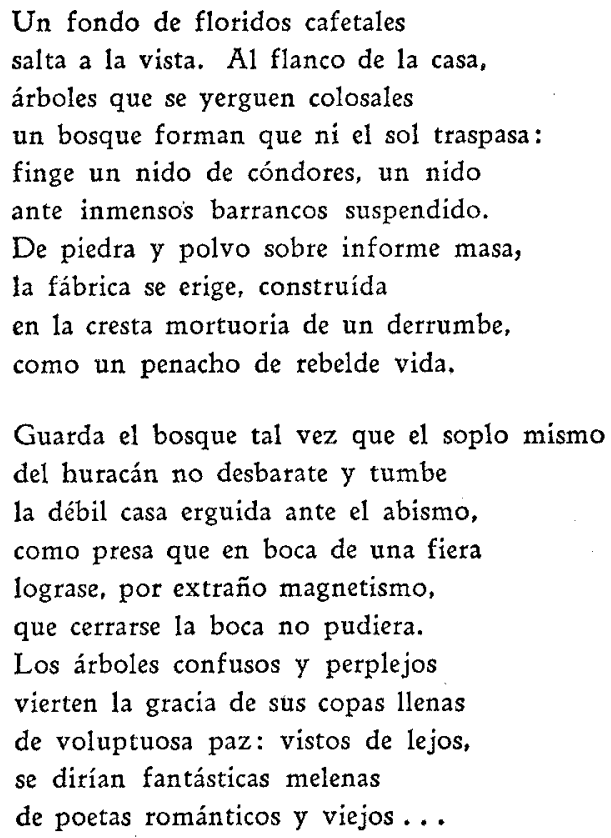


Por detrás de la casa, de lo alto brinca un chorro de plata reluciente, que esforzándose va, de salto en salto, hasta estrellarse en un peñón la frente. Luego da, en tres monstruosos escalones, tres grandes saltos con presteza suma: se hace una catarata que entre espumas retiembla con nerviosas convulsiones; $y$ entonces cede al poderoso aliento de la racha que sopla en el barranco, $y$ se esparce en mil gotas . . como un blanco velo de novia desplegado al viento.

$Y$ ahí, en el fondo, henchido de clamores pasa el rio veloz, que se diría un tropel de caballos trotadores que fuga a escape por la selva umbría.

Anhelando que al fin se desenvuelva su copioso caudal, el río apura el amor que le brinda la espesura: tras la carnal lujuria de la selva. la voluptuosidad de la llanura...

("E1 derrumbe", 1899)

Fácilmente puede el lector avisado y viajero por esas regiones del Perú, reconocer el paisaje abismal y sugestivo del paso de Malalma, con el torrente ligero conocido con el nombre de "El velo de la novia", próximo al lugar denominado "La oreja de Capelo".

Al parecer, Chocano no llegó propiamente a la selva, pues el poema se ambienta en esa región fronteriza en que cubren el Ande declinante las primeras frondas tropicales. Su evocación de Juan Santos no precisaba un marco más extenso, pues su aliento épico reposaba en su idea de fijar el momento heroico del derrumbamiento de la fantástica e impracticable idea de reconstruir el Imperio de los Incas, liquidando un coloniaje secular. $\mathrm{Y}$ así, sólo mucho más tarde, en Centroamérica y no en el Perú, Chocano llegaría plenamente al trópico:

Cuando alcancé una sola sonrisa de la Suerte,

fui al trópico. Vi tanta naturaleza fuerte, que mis ojos, ya hechos a esas grandes visiones, las devuelven ahora dentro de mis canciones. 
cuenta él mismo. En efecto, Chocano se ausenta por primera vez al extranjero en 1901, enviado por su gobierno en misión diplomática a Centroamérica. Este viaje es decisivo en su obra. Allí se le brinda la visión de una lujuriante naturaleza tropical, que es nota tan típica de su poesía posterior y definitiva. Además, Centroamérica se insinúa como el campo propicio para las andanzas aventureras y románticas que caracterizan su biografía.

E1 Perú, como realidad geográfica, se desliga entonces de sus experiencias literarias. Sólo por cortos períodos (de 1903 a 1904, de 1921 a 1922, de 1924 a 1925) volvería de nuevo a la patria. La nostalgia frecuente, que es una de las notas más delicadas en su obra, no pudo suplir en su poesía la falta de esa aproximación a la tierra que tan promisoramente habíase entrevisto en "El derrumbe".

Y comienza su peregrinaje por América: Colombia, la Argentina, los países centroamericanos uno a uno, incluyendo reiteradamente a México y una por una a las Antillas. Finalmente Chile, el refugio de sus últimos años que arrastraron el peso de su segregación del Perú, por motivos que es inútil mencionar, hasta su asesinato en Santiago en 1935.

¿En qué medida es Chocano un poeta de inspiración peruana? En la advertencia preliminar de Alma América, Chocano había definido: "Mi poesía es objetiva." Su objetividad es tan acusada, que no logra coordinar la naturaleza con el espíritu del habitante. Sus visiones del Ande están siempre disociadas de las captaciones del paisaje. Los elementos objetivos de su poesía, lejos de tender a una sintesis cohesiva, se atomizan definidamente. Si examinamos Alma América, su libro con más alusiones peruanas, podemos apreciar que para su criterio artístico la naturaleza se expone en visiones fragmentadas; su concepción del paisaje responde a un análisis cerebral que discrimina en la naturaleza. En los Andes, él aprecia la topografía (la puna), los seres del reino animal (el puma, el cóndor), los seres del mundo vegetal (el maíz), los instrumentos del hombre (la quena). No capta tampoco a una colectividad, ni siquiera a figuras aisladas del hombre actual: su imaginación enfoca siempre a tipos de leyenda como Cahuide, la Nusta, Ollanta, "la última coya."

Si se trata de "la montaña", sus elementos siempre disociados son el río o el bosque; en animales, el guacamayo, el caimán, la boa; en plantas, la magnolia, la piña, las orquídeas, la caoba. En sus poemas no se encuentran complejos o conjuntos de elementos y no con- 
sigue crear una atmósfera específica. Carece de la aptitud para la síntesis artística como paráfrasis de la sintesis natural.

Acaso podrían confrontarse las antecedentes afirmaciones con estos versos, de ambiente selvático y tropical, incluídos en su "Oda salvaje":

Tus matiposas azules y rosadas se abanican como damas coquetas;

tus cantáridas brillan

como las talismánicas piedras

incrustadas en las empuñaduras

de las espadas viejas;

tus chicharras se hinchan clamorosas

en una fiebre de pitonisas coléricas;

$y$ en la pesadilla

de tus noctámbulas tinieblas,

se confunde

el pestañeo de las luciérnagas

con el temblor azufrado

de las pupilas satánicas de las fieras...

Tuya es la danta

que sorprende en los charcos la deformidad de su silueta,

y se va abriendo paso entre los matorrales,

al golpe enérgico de su cabeza;

tuyo el jaguar, que brinca,

en el alarde acrobático de sus fuerzas,

a los átboles corpulentos,

pata dejarse caer súbito sobre su presa;

tuyo el tigrillo, que urde

taimadas estrategias,

para los carnívoros alborozos

de sus dientes de alabastro y sus encias de felpa;

tuyo el lagarto, dios anfibio y vetusto,

que preside las lluvias y las siembras

y condecora con las esmeraldas de sus ojos

las taciturnas oquedades de las cuevas;

tuyo el boa,

que se dijera

un brazo recortado

a las sombras por un hacha dantesca...

("Oda salvaje")

¿Puede esta visión fragmentaria y atomizante llegar a expresar artísticamente el alma de una región? ¿Puede llamarse peruana a 
una producción por el solo hecho de presentar aspectos aislados de lo que constituye el Perú en el espacio? Nos inclinamos a creer que no basta recoger literariamente esos desintegrados motivos de la fauna o de la flora o la geografía de esta tierra para ser consagrado poeta regional. Tanto más que esos temas regionales se agotaron y el poeta no los renovó. No queriendo o no pudiendo permanecer circunscrito a ellos, viró el enfoque y se remotó en el tiempo a las figuras y escenas del coloniaje, explotadas ya literariamente por Palma: el conquistador, el virrey, la tapada, el Paseo de Aguas, etc. Tal reversión parcial e igualmente fragmentada tampoco pudo recoger el alma del país.

La llamada "inspiración peruana" - si con ello quiere expresarse al menos la captación auténtica de un paisaje del Perú- sólo prospera a mi parecer en " $\mathrm{El}$ derrumbe", que como ya se ha anotado, fué producido en circunstancias muy especiales. Otras inspiraciones peruanistas no fueron sino apuntaciones poéticas a textos comunes y accesibles de geografía e historia.

¿Vivían las características del alma nacional en Chocano? El poeta era limeño de nacimiento, pero su fisonomía interior era muy diversa de la que es común a los peruanoś de la costa. Lo ha entrevisto con certeza Ventura García Calderón, cuando dice: "E1 exceso, la exageración no suelen ser limeños y el Chocano adolescente es ya un torrente oscuro, una caótica fuerza sudamericana." Acaso podría ampliarse algo más esta exacta aseveración del escritor peruano... No solamente no son limeñas la exageración y el exceso, sino que tampoco lo, son peruanas. Aún más, ese retórico torrente no es tal vez fuerza sudamericana, sino propiamente caribe o centroamericana. $\mathrm{Y}$ entonces resulta verosímil aquella afirmación que más parece paradoja de café que verdad manifiesta: "Chocano es más centroamericano que Darío." Porque la fronda, el desborde, la sensualidad y las hipérboles, toda la gama del tropicalismo, son más acusados en Chocano que en Darío.

En la América Central -México, Guatemala, Costa Rica, las islas del Caribe, sobre todo- transcurren los años más intensos de la vida del poeta. Es allí donde se encuentra el punto vital decisivo en su biografía; hacia allí van dirigidas sus nostalgias en la madurez. Un designio, revelador en extremo, habia creado tal clima y naturaleza para una sensibilidad afín o, a la inversa, un tal temperamento encuentra allí su medio adecuado. Porque Chocano descu- 
bre en ese paisaje tropical el campo propicio para la expansión de su espíritu y no en la naturaleza varia, profunda y trascendente del Perú. Se dirá que Chocano tuvo acierto en descubrir la selva peruana o, por lo menos, las estribaciones andinas colindantes con ella. Pero no es la selva el paisaje característico del Perú. Lo es, más que nada, el arenal costeño o los oasis de sus valles, la quebrada llena de color y contrastes o la cumbre y el abismo fragoroso de su Ande. En cambio la selva peruana se asemeja a la de cualquier otra zona, o por lo menos a la de muchas latitudes continentales, con las mismas notas de exuberancia y grandeza. 'De allí el americanismo de Chocano, posible sin haber logrado en verdad identificarse con el paisaje del Perú.

"Adivinaba ya Chocano -dice Ventura García Calderón- que sería el poeta de América, superando los intentos criollos de peruanizar la literatura ..." Precisamente Chocano no superó lo peruano, antes bien, logró dar la nota americana sin haber adentrado temperamentalmente en lo pertuano y salvando esa etapa.

¿En qué sentido es Chocano un poeta del Perú? Acaso en la medida en que es poeta continental, que siéndolo del continente es peruano por el vínculo histórico y geográfico que une al Perú con la América, y por ciertas recaladas forzosas que, a fuer de buen americano, hizo en temas peruanos. E1 Perú no es para él un punto de partida, sino una meta ocasional. Por lo demás, esta orientación había merecido, como muchas cosas suyas, una planificación consciente. Escribiendo en La Neblina sobre el americanismo y el regionalismo literarios, diría entonces ya su programa de acción: "seguiremos creyendo y esperando que el regionalismo en literatura va desapareciendo a medida que se van ampliando los medios comunicativos entre los pueblos." Aparte de la falsedad de la doctrina, va aquí implícito el sentido y la explicación de su americanismo, singular porque no encontró ni parangón ni eco. Se explica así que la región propia sea para él lo episódico, la anécdota. Porque la categoría es lo continental, según su estética. Los motivos peruanos no constituían ni la simiente ni la raigambre de su poesía; eran sólo el jaspe o el matiz de las hojas espléndidas y jugosas del árbol de sus creaciones. Su imaginación, extraordinariamente viva y variada, excedió siempre los límites del Perú y aun los del arte, algunas veces. Gustaba elaborar los planes para sus grandes proyectos de soñador. Perseguía convertir en realidad obras fantásticas como el 
canal que uniría el Amazonas con el Océano Pacífico, como la desecación del Golfo de México; soñaba con fortunas provenientes de los negocios mineros que emprendió en Guatemala o los cafeteros en otros lugares de Centroamérica o el descubrimiento de tesoros ocultos que, en Santiago, y en postrera empresa, fué la causa indirecta de su muerte.

Creemos así a Chocano, en rigor, un poeta de América, más que por la revelación del paisaje de estas comarcas, por las calidades intimas de su espíritu literario, muy neto en las cualidades y defectos propios de la literatura de América. Mas aparte de su específica actitud americana, Chocano fué un poeta en el más amplio sentido del vocablo. Si juzgando la obra de juventud pudo Unamuno sostener que era "más elocuente aún que intima", de la producción de los últimos años no hubiera podido decir lo mismo. Allí se reveló integramente la otra faz de su sensibilidad: la aptitud lírica. Pocas veces se ha logrado en la poesía universal una integración tan cabal de épica y lírica en un mismo temperamento creador.

Si restamos de su producción aquellos poemas de los cuales se ha derivado su renombre como intérprete de la realidad y del espiritu de América y lo consideramos sólo en el plano de simple creador de poesía, nos quedan seguramente elementos suficientes y sobrados títulos estéticos para considerar a Chocano como un autor sobresaliente. Con independencia de un falso o exacto sentimiento de la naturaleza, habrá que considerar siempre a Chocano como un gran poeta, orgullo de una raza y de un continente.

En contraste con su ambición de abarcar el panorama estético continental, se encuentra la obra delicada y tenue de otro gran poeta contemporáneo suyo: José María Eguren. Poesía de tono menor, desenvuelta en un delicioso interior, la de Eguren tiene aciertos breves pero encantadores, captando el paisaje nebuloso de los grises aledaños de Lima.

Pero ya hemos salido de los límites del modernismo $\mathrm{y}$, por lo tanto, debemos a Eguren un aparte.

\section{José Maria Eguren}

Eguren ensayó y logró una suerte de poesía original, muy suya, sin precedentes. Lo dominante en ella son los sujetos y objetos de 
un mundo de imaginación, rodeados de una atmósfera de fantasía, en que las situaciones devienen ingenuas, extrañas o misteriosas. Ese mundo interior es tan vigoroso en este poeta, que casi no hay lugar en su vida o en su obra en que intervenga la realidad exterior y cotidiana. No creo fundamental, y puede parecer posiblemente un tanto forzada, esta pesquisa en pos del sentimiento de la naturaleza en Eguren; pero lograría cierto interés para explicar y resaltar, por contraste, sus notas peculiares que prosperan, la mayoría de las veces, desligadas de directos estímulos naturales.

El paisaje real no juega en Eguren un papel sustantivo, a diferencia del que juega, por ejemplo, en José Santos Chocano. Lo esencial de la poesía egureniana se desenvuelve en un escenario interior, poblado de los objetos de la más diversa extracción y procedencia. En nuestro estudio ya citado hemos insistido bastante en caracterizar. ese paisaje interior, sobre todo en sus matices crepusculares $\mathrm{y}$ nocturnos, de tan varia y original concepción. En cuanto a su idea del paisaje real, hoy podríamos responder en la misma forma a la pregunta que nos formulamos hace diez años en nuestro ensayo $L a$ poesía de Eguren (Lima, 1932): “¿Existe paisaje vernacular en Eguren? Bustamante y Ballivián ha hablado de su vida campesina, en sus años de mocedad. No creo que esta experiencia, aparte de unos cuantos elementos muy evolucionados que se advierten en su poesía, haya dado lugar a más... A mi entender, no ha habido claramente una intención definida para tratar el paisaje, porque la conformación poética de Eguren no tolera el predominio de lo objetivo que aquél supone." Una afirmación semejante, exige una demostración que entonces no hicimos y que ahora intentamos.

Si enfocamos a. Chocano, podemos advertir que el paisaje real es inseparable del sentido de su poesía. $Y$ si, por arte mágica, excluyéramos de la obra del autor de Alma América todo lo que tiene de elementos naturales de ambiente, quedaría de ella sólo la sugestión de un inesperado hallazgo de imágenes poéticas, con notables recursos de versificación, pero sin el sello de notoria originalidad y sin el vigoroso impulso épico que estimula en el poeta la naturaleza. En cambio, si el mismo procedimiento pudiera aplicarse a Eguren, en nada quedaría "desnaturalizada" su magnífica obra. Eguren sería el mismo, antes y después del experimento, porque el "ser" de su poesía no está en los elementos objetivos, sino en las creaciones armoniosas de su rica imaginación. 
De otro lado, tampoco Eguren participa de la concepción del "paisaje infinito" que ha caracterizado a algunos simbolistas o neorománticos coetáneos suyos, insistentes en extraer el alma o la mistica del paisaje. Muy lejos está Eguren de identificarse con su contemporáneo Rainer María Rilke, cuando éste dice en Das Studenbuch, haciendo del paisaje un objeto "para si", o aspirando a que el hombre sea él mismo un paisaje:

Sé brezo y pagano, sé ancho.

En realidad, sólo hay dos motivos de paisaje real en toda la obra de Eguren, uno rural, reiterado a través de varias composicionies, y otro urbano, inserto en una de ellas, la plazuela barranquina, ambos perfectamente identificables, pues el campestre se desenvuelve sobre la base de sus experiencias juveniles en la hacienda Chuquitanta en las inmediaciones de Lima, y el citadino en la plazuela de San Francisco, en Barranco, Lima, delante de la que fuera por largos años su residencia. De la primera ha dicho Enrique Bustamante y Ballivián: "Diéronle las primeras (impresiones) no sólo el paisaje que da fondo a muchos de sus poemas, sino el profundo sentido de la naturaleza, expresado en símbolos, como lo siente la gente del campo que lo anima con leyendas y consejas y lo puebla de duentes y brujas, monstruos y trasgos." (Boletín Bibliográfico de la Biblioteca Central de la Universidad Mayor de San Marcos. Vol. 1, Núm. 15.)

El derrotero para desentrañar muchos misterios de la poesía egureniana se encuentra en sus trabajos pictóricos. Entre ellos, el que Eguren estimaba más es un óleo que presenta, bajo cielo gris costeño, un arroyo, cuyas márgenes están pobladas de tupidos cañaverales. Parece ser ese óleo la transposición pictórica de su poema "Marginal", inserto en La canción de las figuras (Lima, 1916) :

En la orilla contemplo

suaves, ligetas,

con sus penachos finos,

las cañaveras.

Las totoras caídas

de ocre pintadas.

el verde musgo adornan,

iluminadas. 


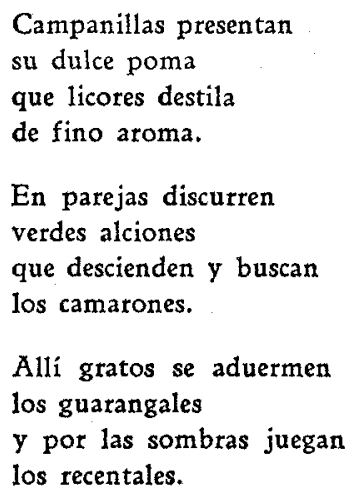

Algunas veces los nombres de plantas, animales o accidentes topográficos no coinciden con los usuales en la región costeña. No debe asombrarnos este hecho, pues Eguren tenía la preocupación de evitar las palabras de mal sonido o de repetición desagradable $\mathrm{y}$ así, en vez de decir "Camaronero", nombre con el cual se designa comúnmente al "martín pescador" en la costa del Perú, usaba "alción", vocablo de uso restringido en castellano, que sirve para denominar poéticamente aquella especie zoológica.

Acequia, cañaveral, guarango y camaronero son elementos animados e inanimados de típico valor en el paisaje costeño. Mas no queda ahí su descripción de la naturaleza costanera. En otro poema, "Alas" (Sombra en Poesias, Lima, 1929), dice:

En la madrugada vi que plañideras

lento descendían las aves viajeras

cerca de la loma, cerca del otero.

dentro de los campos está el perfumero.

Aún pueden hallarse más elementos de paisaje de este tipo $\mathrm{y}$ en forma muy intensa en "Antigua" (La canción de las figuras):

Divisábamos cerro alegre

por el antiguo tragaluz,

la murmuradora compuerta

y los sauces llenos de luz. 
Relinchaban en el pesebre el picazo y el alazán;

Llevarla ofrecimos, fugaces, por la toma, por el jardín, por la cerrada vieja colca y por de la hacienda el confín.

Sonó la campanilla clara seguida de dulce rumor de los tábanos...

La acequia de cal y canto, que iba del estanque al jardín, nos llamaba con el ensueño de madreselva y de jazmin.

La descripción de acequia y jardín, con madreselva y jazmines de tan particular carácter limeño, es muy vivida y más lo será la de "E1 estanque" (Sombra), añadida a una nota de honda melancolia:

El verde estanque de la hacienda, rey del jardín amable,

está en olvido

miserable!

$y$ de tarde la enramada tenía vieja luz dorada;

E1 verde estanque de la hacienda, rey del jardín amable, hoy es derrumbe miserable!

La nota de tristeza, de profunda nostalgia, que caracteriza estas descripciones del paisaje, se acentúa más en esta composición:

En la curva del camino dos tobles lloraban como dos niños. 
Por los lejanos olivos, amoroso canto de caramillos.

("Los robles", en Simbólicas, Lima, 1911)

$\mathrm{Y}$ principalmente en ésta, la más patética, que se titula "La capilla muerta" (Sombra):

Tiembla el sol de la tarde con sus lloros extraños de brillanteces flavas y de carmín profundo; y en la penumbra miro, después de oscuros años, la capilla ruinosa del valle moribundo.

Hoy al santuario vuelvo de la remota hacienda, vetusto, colonial, florido en otros días; $y$ antes que el almavida al meridión descienda, vislumbro sus paredes, sus bóvedas sombrías

miro rondar los mustios, incoloros vencejos.

(Vencejo es denominación culta para golondrina o "santarrosita", como es usual en el Perú.)

Dentro de este paisaje, sólo aparecen contados elementos humanos. Así, en "Antigua" se describe:

Al lado, con grandes espuelas, rezaba ronco el caporal y también los peones que saben misterios del cañaveral.

Y la remembranza infantil, de tiempos idos, está impresa también, como puede verse en "La capilla muerta":

$Y$ los alegres niños en albas estivales nos brindaba la gloria del brillor campesino cuando en la lenta misa, tras de los ventanales, mirábamos la cumbre del monte azul marino. 
La "hermosa, brillante hacienda" de sus años infantiles y de adolescencia, queda imborrable en estos pocos versos, en los únicos en que late la sensación campesina de este poeta de sueños ingenuos.

Otra emoción intensa de su vida, probablemente su ausencia definitiva de la casa luminosa y apacible en que había transcurrido la mayor parte de su vida adulta, va a dictar los versos siguientes que figuran en Rondinelas, libro que contiene los últimos poemas que escribiera. Ellos presentan con cierta vaguedad el panorama constante en sus ventanas. Nos referimos a la casa situada en la esquina de Calle Colón y Plazuela San Francisco, de Barranco, balneario de Lima, en donde conocimos al poeta en 1924, y en la cual residió más o menos hasta 1928:

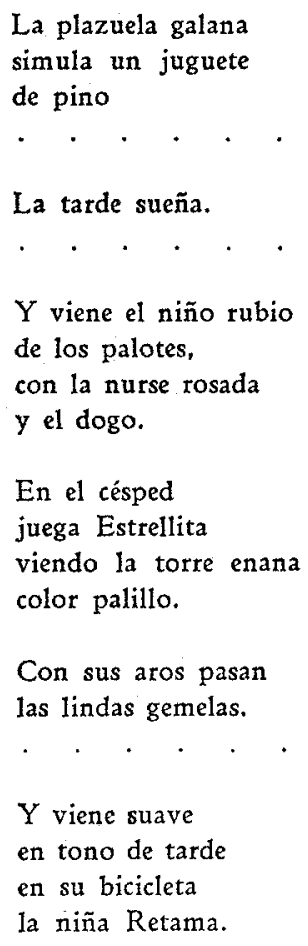

Este pequeño cuadro se completa en "Preludio" (Rondinelas): 


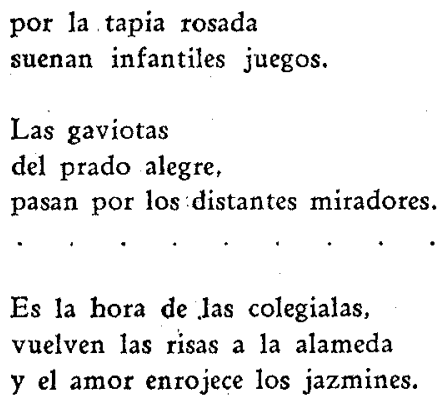

Es la hora de las colegialas, vuelven las risas a la alameda y el amor enrojece los jazmines.

El paisaje real, en breves esquemas, abre y cierra así el ciclo de producción de Eguren. Son sus dos fases la experiencia campesina en sus años juveniles y la observación delicada de los niños en la plazuela barranquina, en la etapa del tramonto. Ambas lucen experiencias doradas con la nostalgia y la tristeza de lo que se ha perdido, la hacienda y la casa, integrantes del patrimonio familiar, como en el Virgilio de las Eglogas, nostálgico de la finca del Mincio, la heredad paterna testigo de alegrias infantiles.

La poesía de Eguren adopta caracteres propios, inconfundibles, que le están conferidos por su extraordinario mundo de imágenes ingenuas y misteriosas, por sus sensaciones de pureza lírica incomparable, por su selección del vocablo y de la idea.

Pero si bien en su mundo interior se agolpan las imágenes tan típicas suyas, frente al paisaje real adopta una actitud distinta, que en su esencia es mucho más simple y primitiva. La naturaleza objetivamente vista es sólo el marco para ofrecer sensación de cierta nostalgia de tiempos idos de juventud o de visiones definitivamente perdidas, envueltas en niebla costeña y en recóndita tristeza. En esa actitud puede advertirse una raíz romántica, la cual, sin embargo, no prospera en todo lo demás de su obra, situada tan cerca de los módulos de la poesía. Porque de todo lo que llevamos visto de su concepción de la naturaleza, no se puede deducir que aquella actitud sea la predominante, ni la definitiva, ni la caracteristica de toda su obra. Apenas constituye esta captación del paisaje natural una nota esporádica, aislada, fragmentada, sin que ello signifique negarle fuerza ni originalidad. El anotarla sirve para demostrar el hecho hermoso y significativo de que las más altas cumbres de selección y de arte 
purísimo suelen enraizar su estructura en el ambiente que las rodea y sentir en su fibra más intima y profunda la irrenunciable determinación de la atmósfera y el panorama circundante. Este aspecto de la poesía egureniana nos confirma la compatibilidad de la práctica de un arte exquisito con el respeto de los dictados de esa indestructible ligazón existente entre el hombre y la tierra.

\section{La nueva poesía}

Acaso el nuevo poeta, adentrándose en su propio paisaje, está contribuyendo a fijar y a definir algo que es la raíz del estilo de vida de su pueblo.

En un libro reciente (Panorama actual de la poesía peruana, Lima, Editorial Antena, 1938), el autor ha tratado de formular un derrotero de la nueva poesía del Perú, ya que hoy coexisten diversas tendencias relativamente autónomas y con pocos vínculos de relación entre sí. Hemos creído encontrar tres direcciones dentro de las cuales puede distribuirse la nutrida producción de los numerosos poetas: el purismo, el expresionismo regionalista y el neo-impresionismo.

1.-Una de estas tendencias poéticas es el purismo. Los poetas de este tipo cultivan el paisaje subjetivo, interior, sin vínculo directo con el real. Como siguen la fluencia de las motivaciones subconscientes, arriban necesariamente al paisaje sobrerreal. $\mathrm{Y}$ así implica esta tendencia la abolición y la negación del paisaje objetivo, con ciertas variantes explicables en cada temperamento.

En Enrique Peña impera un creacionismo natural que da su fruto en un paisaje hecho a su imagen y semejanza. Peña muestra una naturaleza mágica, con una zoología y una botánica muy sugestivas y artísticas. Sus paisajes interiores están poblados con seres inesperados, como un "animal primitivo mordedor de luceros" y otro "animal rosado que se traga los violines". Crecen en ellos unas plantas con dientes y un clavel alado.

En tanto, Emilio Adolfo Wesphalen y otros poetas afines, como José Alfredo Hernández, se inhiben literariamente de conocer la naturaleza real. Extraen de ella, es verdad, elementos imprescindibles que después combinan en caprichosa y artística obra de creación. Al lado, Xavier Abril ensaya un sobrerrealismo sintetista que recom- 
pone con esos elementos aislados de que hacen uso los anteriores, un paisaje interior total, el cual no corresponde a la naturaleza de región alguna del globo terráqueo. Obtiene así, con cierta aptitud barroca, un paisaje-síntesis, un paisaje estilizado que es de todos los lugares $\mathrm{y}$ de ninguno:

\section{Fuego Oculto}

(Un monasterio bizantino de hombres y mujetes ciegos, libertinos, obscureciase en la dura noche roquera, en la plaza del mal agüero. Azul de venas perdido; nariz carcomida sin perfil, de oro muerto, egeo.)

Las cúpulas del cielo sin fieles, tumbadas al mar de lo deshecho, de lo que sin espuma clama. Y sin dientes. La espuma de la resaca resucita beodez antigua de bizantinos suplicios, los más premiosos placeres de uña sin existencia.

El azu1 y el oro difuntos ocultan los senos de las vírgenes en retablos de musgo.

El azul languidece en rito y el oro en goce sepultado.

El fuego oculto de las ruinas aviva y violenta perfiles desdibujados, curvas cruentas, aristas punzantes, grietas, sexos y lenguas.

Olas bravas tiran de las estatuas y de las rejas; enfurecidas olas, corrientes adversas cavan tumbas antiguas que mudaron de sitio.

(Pájaros asesinados son descritos en palabras prehumanas, en símbolos. La geometria basta a la verdad, al misterio. De esta suerte, el dolor queda grabado: nadie lo negará sino en batallas.)

Las fechas borrosas en las lápidas; el amot en las fechas y en las flores, renovados dias.

Los huesos dispuestos en el silencio, en fosas, trabajan al fondo del tiempo, entre corrientes mortales de gas.

(De Dificil trabajo, Madrid, 1931)

Tenemos así un paisaje insólito, extraterráqueo, con ilimitadas distancias y densidad extraña. Creemos que Abril logra hasta ahora, en la poesía peruana, la más original muestra de paisaje interior.

2.--Mientras que los puristas superan el paisaje real y objetivo, los expresionistas lo acogen cálidamente. Pero no se detienen en el paisaje sino en cuanto el habitante necesita de un ambiente circundante para lograr toda su plenitud humana. Por eso cabe afirmar que los expresionistas aprecian el paisaje a través del hombre, como un marco necesario, ponderable e inevitable. Para ellos no hay ni 
paisaje absoluto ni abolición de naturaleza. Adoptan la posición intermedia entre puristas e impresionistas. Dentro de esta línea del expresionismo regionalista hay, por supuesto, matices a cual más sugestivos.

Empecemos por Vallejo y sigamos luego observando la actitud de Alejandro Peralta y José Varallanos, los más calificados exponentes de la sensibilidad para el paisaje.

En César Vallejo la naturaleza se adivina casi, apenas se expresa. Se respira, se aspira el paisaje en escenas de intensa humanidad. Sin él proponérselo, nos ofrece a retazos una visión recortada y esencial del pueblo encajado entre los Andes, rústico y pobre:

Gallos cancionan escarbando en vano

Boca del claro día que conjuga

Rumbé sin novedad por la veteada calle que yo me sé. Todo sin novedad, de veras...

Doblé la calle por la que raras veces se pasa con bien, salida heroica por la herida de aquella esquina viva, nada a medias.

amanece lloviendo. Bien peinada la mañana chorrea el pelo fino

Cielos de puna descorazonada por gran amor. Los cielos de platino, torvo de imposible

Rumia la majada y se subraya de un relincho andino.

Me acuerdo de mí mismo. Pero bastan las astas del viento, los timones quietos hasta hacerse uno, y el grillo del tedio y el joboso codo inquebrantable.

(De Trilce, Lima, 1922) 
La honda melancolía que domina en toda la poesía de Vallejo, caracteriza también su sentimiento de la naturaleza que, en él, es pretexto para sus humanas disquisiciones, instrumento de su expresión intensamente vital. El paisaje no tiene en Vallejo significado en sí: es marco precioso, pero al fin sólo marco, para acoger al hombre.

Muy lejos de la directa descripción, la poesía de Vallejo deja percibir el paisaje a través del personaje de sus poemas -él mismo-, siempre nutrido de trascendentes experiencias vitales.

Más expansivo, menos recóndito es el sentimiento de la naturaleza en Alejandro Peralta. Hay en su obra la voluptuosidad de describir intensamente, casi con un impulso dionisíaco. Pero aun así, siempre el paisaje queda subordinado al personaje, al hombre:

el silencio se desmorona frente a la cabalgata

marejadas de relinchos brinca al amanecer sobre las peñas

la aldea desnuda sus vértebras de piedra

la campana de la iglesia navega hacia la pampa

Bebemos el primer alcohol matinal

El sol está limpiando los tejados

en las crines de los caballos enredamos la alegría

El día va sujeto a los estribos

lejos

vuela el armazón del pueblo.

La pampa abre su tienda de montañas

llenamos de oxígeno nuestras alforjas

el camino desdobla sus veredas de tierra firme

del norte viene una polvareda de palomas

$y$ en el alto estalla la pirotecnia de los loros

En marcha

proyectiles de amanecer nuestros ojos perforan

la tela del horizonte

Un cortejo nupcial de indios de la comarca

ciñe la cintura del cerro de gala

monteras de geráneos rebozos como llamaradas

refulgen pitos y tamboriles.

("Travesía andinista", en El Kollao, Lima, 1934) 
Con José Varallanos adquiere el paisaje más perfilada autonomía. Aunque no falta el elemento humano, porque su "hombre del Ande" aparece siempre adentrado en su medio. Pero es autónomo en la medida que se desprende de localismo. Para él no hay regiones dentro del Ande, hay sólo un Ande despojado de sus elementos accesorios $\mathrm{y}$, concentrados esos otros elementos fundamentales, nos ofrece una visión mágica y eglógica de la serranía peruana:

Provinciana de 15 años, la aldea se ha quedado enternecida entre los quishuares huanucuyus.

Los pájaros dejan caer la semilla de sus cantos desde los árboles dulces en flor. estos pájaros aborígenes que han picoteado el ritmo de una voz.

El viento al pie del horizonte duerme.

el viento que se emborracha de movimiento y ya no silba arriero levantando los caminos y a sus pasajeros aldeanos.

Al fondo, una lomita fresca de sombrios peinada de color ñusta fuerte, salta, salta y llega al corazón,

alegría, alegría de los vestidos campesinos: de los pullos roidos.

de los ponchos cantarinos, de las bufandas crepusculares.

E1 sol está floreciendo en las papas, en los pastos, en las tapias.

Por encima de nosotros la torre se santigua.

E1 domingo va divisando desde el campanario pastor de las casas.

El camino es un verso tendido hacia el río

que corre alegre como un muchacho quechua.

Los cerros mozos juegan a la ronda, a la ronda, encerrando el valle

La cintura del valle amarrada con la faja de un jardín silvestre.

(De Et hombre del Ande que asesinó su esperanza, Lima, 1929)

El expresionismo ha tomado los elementos de la naturaleza no sólo como fuente de símbolos y figuras literarias - concepto al que fueran tan afectos los impresionistas-, sino además profundizando en ella, con rara aproximación, considerándola como portadora de una vida autónoma, en la cual se tiene participación y a la cual está vinculada la propia vida del poeta. 
3.-En la tercera tendencia poética actual del Perú, que hemos convenido en llamar neo-impresionismo, el paisaje tiene culto más nutrido, aunque no en un sentido absoluto. Porque hay poetas de este tipo que no recogen ninguna impresión regional, como Oscar Imaña, y hay otros que colectan el paisaje intensamente. A estos últimos se refieren los apuntes que siguen, en que se estudia a los que impresionan la emoción de la tierra en el hecho o en el habitante o a los que, sin vincular el paisaje a una anécdota dada o a un hombre, lo tratan simplemente como tal, sin mácula de elementos extraños.

En los nuevos impresionistas se reconocen todos los aspectos del paisaje peruano, excepto la selva. El Amazonas, los ríos de nuestra "montaña", parecen hasta ahora el patrimonio exclusivo de los prosadores.

Pero en estos poetas se adentra la costa y aún más la sierra, en todas sus variadas facetas de maravilloso paisaje. E1 Ande ha atraído con fuerza singular - mediante su colorido brillante, sus pétreas masas, el contraste de tonalidades y la cósmica atracción- el interés de la poesía.

Acaso podemos insinuar un recorrido turístico por el Perú, a través de nuestros poetas. En primer lugar, la costa, que viera en su color mulato Enrique López Albújar -en libro que consideramos más de prosa que de poesía- y que antes vió en su expresión marina Alcides Spelucín, quien aprendió a observar la sugestión del mar en playas caribes.

Con marco de paisaje costeño, prospera una poesía costumbrista y un poco nostálgica. Era así inminente esta cita de José Gálvez, el evocador de la Lima que se está yendo.

Saliendo de la costa, el color y la fuerza andinas ya se precisan dentro de un cuadro inconfundible, en Arequipa, ciudad de blancura purísima y de purísimas expresiones poéticas. Nunca ha podido desligarse el poeta arequipeño de la atracción cálida y optimista de su paisaje sugestivo. Casi podría afirmarse que sólo prosperará en la ciudad de los volcanes una poesía impresionista por determinismo telúrico. $Y$ alli han dicho su verso en estos años Gutillermo Mercado y Alberto Guillén, cantores del arrabal y la campiña, tan peculiares y que tanto personalizan a la ciudad mistiana.

Aquí viene la impresión de Sachaca, pueblucho de los alrededores, por Guillermo Mercado: 
Sobre tus casas todavía mi corazón

como una cometa regocijada

que yo jalo y elevo y le suelto todo el hilo de mi recuerdo.

Ese domingo, Sachaca, estabas de fiesta,

parpadeabas de pendones y tus techos gritaban sobre el campo.

Estabas lleno de los arcos del triunfo

que levantaban el canto de tus gallos.

Tus callejones desdoblaban y estiraban sus acuarelas

que, de repente, se iluminaron con el ladrillo chillador de los perros.

Una bandada de repiques descendía del cielo

a picotear a tus árboles:

hasta tus ancianos tenían en la cara rumiando alegria

sus ochenta años afeitados

y el sol, todo el sol en tu plazoleta

era una bandada de pájaros ensordecedores.

(De Tremos, Arequipa, 1933)

El paisaje del Ande mismo tiene múltiples cultivadores en todos los meridianos geográficos; en Huánuco se han detenido José Varallanos y también Luis Fabio Xammar, cantor de Yanahuanca, en estos versos:

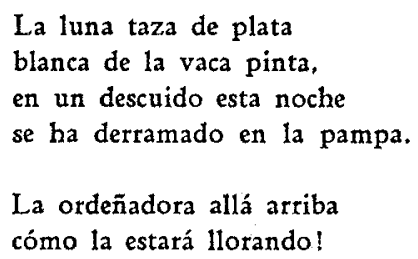

Otro:

La hacienda recostada

sobre almohadones de nieve.

Trasquilaré para ti

los vellones de las nubes

-y estoy seguro que llueve-.

Y tú, cholita callada

¡qué cara alegre pondrás

al pensar en nuestra chacra!

(De Wayno, Lima, 1937; 2a ed., 1942) 
En Junín, Enrique Bustamante y Ballivián encontró las impresiones que reunió en un libro de viaje y poesías. De él es este "Amanecer":

Trina el silencio, trina el aire,

y trina la sombra estremecida por la luz que la despierta $y$ de nuevo le hace abrir los ojos para el claro milagto.

Lenta, sobre los altos picos abrigados: todavía, por la levedad de la niebla, aparece la luz.

Trémula y pálida, temerosa de quebrarse en las escarpadas pendientes andinas va descendiendo a las quebradas $y$ tomando humano color de fuego $y$ de sangre.

Los claros trinos se funden con los clamores, con las angustias, con los deseos, en una creciente armonia grave.

(De Junin, Lima, 1930)

Al rasgo severo de Bustamante, se agrega esta nota de cristalina autenticidad y de sensaciones exquisitas, aportada por Ricardo Peña, viajero por esas mismas regiones:

Las tardes que fueron mías allá en los bosques de mayo, que bañan el dulce anhelo del terco rio Mantaro.

Las tardes que fueron mías.

Allá no más, en la orilla, un puentecito hecho olvido, iba y venía en el aire sonando como un silbido. 
Bajo la fronda callada a media luz la escuelita alumbraba el caserío, los cristales de la ermita.

En los bosques de rodillas, descalzos, casi con hambre, deletreaban los chiquillos el $a b c$ de las aves.

Qué pena la de esos pueblos. Cuánta angustia en esas tardes en que yo iba a embriagarme de inaccesibles amantes.

Qué alegría, qué alegría la de sentirme entre ellos, así, mezclándome, oyéndolos, fundiéndome en sus recreos,

haciendo consuelo a un coro de canciones que elevábanse de la torre de la ermita, tan triste, pobre, olvidada.

("Romance de la ermita" en Romancero de las sietras, Amazonas, Perú, 1939)

En Puno, muchos poetas de estos dias captan el paisaje del Lago, dentro de tal modalidad impresionista. Tampoco en Puno pueden sustraerse los poetas al maravilloso espectáculo del Titicaca, en su cielo, en sus aguas, en sus orillas, en sus islas, en toda su soberbia grandeza y en su habitante recio y espléndido. De ese grupo de poetas puneños en que están Alejandro Peralta, Emilio Armaza, Emilio Vásquez, Dante Nava, extraigo la voz de Aurelio Martínez. Así nos dice en su poema "Chacras Musicales":

están gritando las chacras con sus llijllas $y$ en la ladera se envuelven los caminos luciendo sus chumpis nuevos poemas verdes son las pampas frente al lago 
por todas partes los surcos danzan

amanecidos con tonos de luz nueva

cantando sus huaiños frescos

llenos de las virtudes del agua creadora

aquí están las chacras altipampas

llenas de los sudores raciales

endulzadas por las mieles del sol

y las leches que brotan de la tierra

chacras florecidas por el ritmo de las lluvias

que sugieten músicas religiosas

en las hojas y en las flores

chacras de los verdes emocionados

chacras de las flores kantutecidas

yo sé de las ternuras de las manos indias

empolvadas en la faena gloriosa

llenas de la alegría de un agua que corre

de los indios chacareros

yo sé de sus afanes fecundadores

$y$ de su amor agricultor

que se sintetiza en el fruto sabroso

(el fruto

que es una metáfora de prodigio universal

dicha por las grietas de la tierra

para que la escuchen los indios)

yo sé de las fiestas infantiles

de los frutos bajo la tierra

y de los que mecen en el aire

contentas brisas de las chacras en cosechas colores coladores de llijllas en el campo polleras en fiesta de las imillas enteras

las tinconadas han sacado de sus cajas los mejores tonos de la luz de abril

el paisaje es una fuerza de óleos firmes que deja manchas en el espíritu 


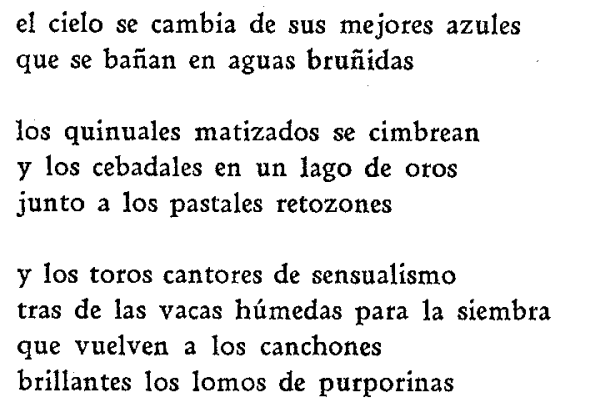

(Poema inédito)

El sabor eglógico que fluye de este poema tiene escasos antecedentes dentro de la poesía peruana. Acaso la visión humilde y sentida del campo no ha interesado vastamente como tópico poético. Desde los "cuadros" virgilianos de Juan de Arona, impregnados de gracia costeña, de arenal y de niebla, no ha habido hasta estos días ningún otro cantor rústico. De los románticos, ninguno quiso sacudirse del desdén por la visión cabal de la naturaleza simple. Ellos arribaron ansiosos a la encrucijada del "paisaje rubeniano", delicado, pulidísimo, pero convencional. Ahora se restituye la imagen certera y directa del campo y del hombre campesino en la lírica.

Variada suerte ésta del paisaje dentro del múltiple esquema de la poesía actual del Perú. Si queda todavía algún recodo o sector de nuestra geografía que no ha llegado a la pupila del poeta, ello no significa sino que quedan aún muchos estímulos para la poesía de mañana.

Si bien no hay todavía en la cartera del poeta todos los colores $\mathrm{y}$ todas las formas de nuestra naturaleza, en cambio, en lo ya creado y recogido vibra la emoción de la tierra, con varia fortuna en cuanto a la perfección y logro de la forma literaria, pero honda y plenísima de sinceridad.

Estuardo Núñez, Lima. 